http://kitaibelia.unideb.hu/

ISSN 2064-4507 (Online) • ISSN 1219-9672 (Print)

(C) 2016, Department of Botany, University of Debrecen, Hungary

22 (1): 84-94.; 2017

DOI: $10.17542 /$ kit.22.84

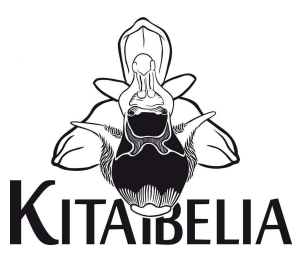

\title{
Az adriai sallangvirág (Himantoglossum adriaticum) magyarországi állományai és lelőhelyeik tájhasználatának története
}

\author{
BóDIS Judit \\ Pannon Egyetem, Georgikon Kar, Növénytudományi és Biotechnológiai Tanszék, H-8360 Keszthely, Festetics u. 7.; \\ sbj@georgikon.hu
}

\section{Hungarian localities of Himantoglossum adriaticum and its land-use history}

\begin{abstract}
Himantoglossum adriaticum H. Baumann is a Natura 2000, CITES species and strictly protected plant in Hungary. During my field work (1992-2016) I realized some similarities in the characteristics of the habitats where the plant grows, so I wanted to know the land use history of the areas in question. The H. adriaticum population of Keszthely Hills was studied the longest time. There were annually 7-78 inflorescences between 1992-2016. Recently two further localities were found in Keszthely Hills. They grow in the edges of grasses used earlier as pasture, minor roadside verges and nearby abandoned vineyards. The largest population can be found in Sümeg region, majority of the individuals are along a paved road. Among the estimated 1000-2000 individuals 10 (2012) to 214 (2014) flowered. In Kőszeg, the lizard orchid grows in abandoned vineyards and in old traditional orchards. The maximum number of inflorescences was 165 (2016). In Bakony Hills its habitats are vineyards and orchards abandoned approximately 50 years ago. The size of $H$. adriaticum population here is nearly the same as in the Keszthely Hills. Four out of the five populations are growing on sites used as vineyard or orchard already in the years of the First Military Survey. The only exception is the population of Sümeg region. Every habitat is threatened by spontaneous forestation, but the species is able to find new habitats, so we do not worry about the drastic decline of the individuals in Hungary.
\end{abstract}

Key words: abandoned vineyards, land use history, Orchidaceae, roadside verges, size of populations, traditional orchards

Összefoglalás: Az adriai sallangvirág (Himantoglossum adriaticum H. Baumann) Magyarországon fokozottan védett, közösségi jelentőségű növényfaj. Hazai állományait 1992 óta vizsgálva, a területek egyes sajátosságainak hasonlóságait észleve, fordult érdeklődésem a lelőhelyek tájhasználat története irányába. Az általam legrégebb óta nyomon követett populáció a Keszthelyi-hegységben található, ahol 1992 és 2016 között 7 és 78 között változott a virágzó egyedek száma. Újabban két kisebb állománya is előkerült a fajnak a hegységből. Az állományok egykori legelő szegélyében, földút mentén, illetve szőlők közelében vannak. A legnagyobb populáció a Sümeg-Tapolcai-háton található, nagyobbrészt a közút szélén. A megfigyelt években mintegy 1000-2000 egyedből a virágzó példányok száma 10 (2012) és 214 (2014) között váltakozott. Kőszegen, a város szőlőhegyén magánkertekben, extenzíven kaszált parlagokon és gyümölcsösökben találhatóak, ahol összesen akár 165 (2016) virágzó tő is lehet. A Bakonyban kb. 50 éve felhagyott szőlők és gyümölcsösök helyén találhatók, az állomány nagysága kb. a Keszthelyi-hegységivel azonos. A hazai öt állományból négy helyen van, ahol (vagy a közelében) már az I. Katonai Felmérés idején (1783-84) szőlő- vagy gyümölcsöskert volt. Ez alól csak a Sümeg-Tapolcai-háton lévő populáció kivétel. A sallangvirágok számára a legjelentősebb veszélyeztető tényező a becserjésedés, de a faj képes új helyeken megjelenni, bízhatunk állományainak fennmaradásában.

Kulcsszavak: felhagyott szőlők, hagyományos gyümölcsösök, kosborfélék, populáció méret, tájtörténet, útszélek 


\section{Bevezetés}

Az adriai sallangvirág (Himantoglossum adriaticum H. Baumann) fokozottan védett, közösségi jelentőségű növényfajunk. Természetvédelmi értéke 250000 Ft. Szerepel a Vörös Listán, aktuálisan veszélyeztetett (NÉMETH 1989), illetve veszélyeztetett taxonként (IUCN 2001, KIRÁLY 2007).

Bár ma már tisztázott a taxonómiai helyzete, s teljesen elfogadott faji önállósága (SRAMKó et al. 2014, BATEMAN et al. 2017), mégis viszonylag kevés adattal rendelkezünk a faj elterjedéséről és biológiájáról, hiszen csak 1978-ban írta le BAUMANN (1978). Ez az oka, hogy az 1990-es évek közepéig Magyarországon az egyetlen publikált H. adriaticum lelőhely a Szabó István által 1974-ben megtalált és H. hircinum néven közölt (SzABó 1987) Pilikán-Szoroshadi állomány volt (MoLNÁR V. et al. 1995). Szisztematikus munkával, az irodalmi és herbáriumi adatok feldolgozásával és a lelőhelyek felkeresésével újabb állományok kerültek elő, melyekről átfogó képet nyújtott SULYOK et al. (1998). A Magyarországon előforduló Himantoglossum fajok hazai elterjedéséről szóló ismertetésükben beszámoltak arról, hogy Berecz József a Sümeg-Tapolcai-háton is megtalálta a fajt, amely a részletes felmérés során a pilikáni állománynál is nagyobbnak bizonyult. A Keszthelyi-hegységből további, legfeljebb néhány virágzó töves előfordulásokat soroltak fel a rezi Várhegyről, a várvölgyi út mellől és a Négyszögűhegyről. Szinte ezzel egyidőben a növény a Laitaicum területén, a Harkai-kúpon is előkerült (TímÁr 1997). 1995-ben a Bakonyban, a Nagytevel községhatárában fekvő Öreg-hegyen az adriai sallangvirág nagy állományára talált BARTA (1998); az egymástól mintegy 1 km távolságra lévő szubpopulációkban kettő, ill. száz tő virágzott. 2007-ben újabb lelőhelyről számolt be BAUER (2007) a közeli bakonyjákói Német-cserről. A Kőszegi-hegységből addig kipusztultnak hitt sallangvirágot 2004-ben találták meg újra, valószínűleg ugyanott, ahonnan a faj korábbi irodalmi és herbáriumi adata is származott (KIRÁLY \& MESTERHÁZY 2005). Lájer Konrád a Rendeki-hegyen, Szilaj Rezső Balatonedericsen, a Sipos-toroktól nyugatra talált virágzó tövet (Sulyok ex verb.), amelyek a Magyarország orchideáinak atlasza térképén (BóDIS et al. 2011: 375.) is megjelentek. Az utóbbi években Óvári Miklós a Zalai-dombságban négy helyen is talált egy-egy példányt (ÓvÁRI 2017), melyek közül kettő a Magyarország orchideáinak atlasza térképén is szerepel.

Jelen közlemény célja, hogy egyrészt dokumentálja a faj hazai állományainak nagyságát, helyzetét, másrészt bemutassa az élőhelyek tájhasználatának történetét, amely megismerése segíthet megéretni a faj biológiájának sajátosságait és segítséget jelenthet a faj aktív védelmében is.

\section{Anyag és módszer}

A faj herbáriumi adatai a Magyarországi Orchideák Herbáriumi Adatbázisából (MoLNÁR V. et al. 2012) származnak. A fajjal kapcsolatos terepi vizsgálatokat 1992-ben kezdtem a keszthelyi állományban, a többi hazai termőhelyre kiterjedő adatgyűjtések - már segítőkkel - 2010-től folynak. A terepi munka során évente felmértük a virágzó tövek számát (19922016), illetve 2012-2014 között a vegetatív töveket is. A virágzó egyedeket júniusban, a vegetatív töveket márciusban számláltuk. A felmérésben a legrégebben és legalaposabban tanulmányozott keszthelyi-hegységi állomány a többi populációnál részletesebben szerepel.

Az egyes területek tájhasználat-történetét a Habsburg Birodalom Első [1] és Második [2] Katonai Felmérésének térképeinek, a Magyar Királyság 19. században készült kataszteri térképeknek [3], valamint 1959-2015 között készült georeferált légifelvételek [4, 5] alapján jellemzem. 


\section{Eredmények}

Az adriai sallangvirág magyarországi állományának nagysága

Magyarországon a faj számára legkedvezőbb években mintegy 5000 megjelenő tőre lehet számítani, jó esetben kb. 10\%-uk jut el virágzásig (1. táblázat). A „rossz” évnek számító 2012-ben a vegetatív tövek száma ennek csak fele volt. Ekkor mindössze 22 virágzatot találtunk az egész országban, ami 4\%-a a legmagasabb értéknek (539 virágzat, 2014-ben). A legtöbb növény a Sümeg-Tapolcai-háton lévő populációban van: országos összehasonlításban évjárattól függően a vegetatív tövek 40-60\%-a, a virágzó tövek 30-45\%-a itt jelenik meg. Nagyságban ezt a kőszegi állomány követi: itt a hazai állomány vegetatív töveinek 18-25\%-a, a reproduktív tövek 10-38\%-a jelenik meg. A bakonyi és keszthelyi állomány mérete nem különbözik egymástól jelentősen: a vegetatív hajtások 10-15\%-a, a virágzók 14-21\%-a (Bakony) illetve 16-32\%-a (Keszthelyi-hegység) található meg ezekben. Stabilnak mondható még a Harkai-kúpon lévő állomány, ahol a vegetatív tövek száma száz alatti, s pár virágzó példányra lehet évenként számítani.

A magyarországi állományok lelőhelyei és tájhasználati vonatkozások

\section{Keszthelyi-hegység}

A Keszthelyi-hegységből 9 herbáriumi lapról van tudomásunk. A rezi Várhegyről Papp János (1953. 06. 28; BP) példányát ismerjük. Boros Ádám a gyenesdiási Ló-hegyen (1950. 06. 16; BP) gyújtötte a fajt és Almádi Lászlónak is megmutatta a helyet. Almádi 1965-ben még gyűjtött onnan a növényt (PE Georgikon), de az utóbbi évtizedekben a rendszeres keresés ellenére sem került elő. Két lap származik a Büdös-kút környékéről (Vajda László, 1935. 06. 14; BP és Károlyi Árpád, 1960. 06. 25; BP), ahonnan szintén nincs azóta adatunk. Egy-egy lapon Vonyarc, illetve Balatongyörök, kettőn pedig Keszthely helymegjelölés található, pontosabb lelőhely nélkül.

\section{Pilikán-Szoroshadi út}

A legrégebb óta ismert állomány, amelyet Szabó István talált meg 1974-ben, és 17 virágzó tövet számlált ezen a helyen (SzABó 1987). Összesen kb. 2 km hosszú az az útszakasz, ahol a sallangvirágok nőnek, néhol nagyobb csoportokat alkotva. A földút két oldalán az erdőszegélyben váltakozó szélességű füves-cserjés sáv, ill. kisebb füves tisztások vannak. A földút aszfaltozott erdőgazdasági üzemi útra vezet ki, ahol további sallangvirág előfordulások vannak. Az útvonal megegyezik a Magyar Posta Kábel nyomvonalával, amelynek jelzőoszlopai mindkét oldalon megtalálhatók.

A terület déli része egykori legelő, a kétoldalt húzódó dolomitrögök közé benyúló, homokkal bélelt, elkeskenyedő völgy, amely kb. $1 \mathrm{~km}$ után éri el a Büdöskútra vezető aszfaltozott utat. Az I. Katonai Felmérés idején az erdők északabbra kezdődtek, mint napjainkban, és legelőként voltak használatosak a településhez közelebb eső dombok. Továbbá jelentős volt a szőlőtermesztés a környéken (2. ábra - Elektronikus melléklet). A legeltetés az archív légifotók tanúsága szerint a dolomitrögökre is kiterjedt, de ez a használati mód a 20. század közepére visszaszorult, és fokozatosan cserjésedni kezdett a terület. Az 1950-es években, több hullámban, széles sávokban feketefenyővel (Pinus nigra) telepítették be a dolomit területet, míg a mélyebb termőrétegü, homokos völgyaljat az 1960-as évek végén kocsánytalan tölgygyel (Quercus petraea) ültették be (2. ábra - Elektronikus melléklet). A fásításokat követően a gyep kiterjedése a töredékére csökkent, a völgy aljára, az azon átvezető út mentére korlátozódott. A fásszárú vegetáció megerősödésével különböző mértékben fenyő elegyes mészkedvelő tölgyesek és bokorerdők váltakoztak az út mentén. Az élőhely déli részének dupla föld- 
útja a keszthelyi laktanya lánctalpas harckocsijainak lett katonai gyakorlóterülete. A katonák a sallangvirágok élőhelyéül szolgáló tisztásokon táboroztak a gyakorlatok ideje alatt.

1. táblázat. A H. adriaticum állományok példányszámai. A virágzó tövek száma mellett zárójelben a vegetatív tövek száma szerepel. A 2012-2014-es adatok tartalmazzák az újulatot is, a többi esetben csak az ivarérett egyedek száma ismert. A keszthelyi-hegységi szubpopulációk jelölése: 1 - rezi Várhegy; 2 -

Fagyoskereszt; 3 - Négyszögű-hegy; 4 - Tüskés lap; 5 - Bottyán-hát; 6 - Pilikán-Szoroshad. A felső indexben szereplő számok a következő forrásokra utalnak: ${ }^{1}$ TímÁR (1997), ${ }^{2}$ FHNPI, ${ }^{3}$ Király \& Emődy ex verb., ${ }^{4}$ Takács \& Udvardy ex verb., ${ }^{5}$ KIRÁLY \& MESTERHÁZY (2006), ${ }^{6}$ Markovics \& Emődy ex verb., ${ }^{7}$ BARTA (1998), ${ }^{8}$ BfNPI (Cservenka J.), ${ }^{9}$ SulYoK et al. (1998), ${ }^{10 Z}$ Zöld Zala Természetvédő Egyesület (Óvári M.)

Table 1. Population sizes of H. adriaticum detected in Hungary after 1992. After the number of flowering plants in parentheses the number of vegetative individuals is signed. Data between 20122014 include recruitments, in other years only the adults were counted. Numbering of sub-populations in Keszthely Hills are as follows: 1 - Rezi; 2 - Fagyoskereszt; 3 - Négyszögű Hill; 4 - Tüskés lap; 5 Bottyán-hát; 6 - Pilikán-Szoroshad. Upper case indices mean the following sources: ${ }^{1}$ TímÁr (1997), 2FHNPI, ${ }^{3}$ Király \& Emődy ex verb., ${ }^{4}$ Takács \& Udvardy ex verb., ${ }^{5}$ KiRÁLY \& MESTERHÁzY (2006), ${ }^{6}$ Markovics \& Emődy ex verb., ${ }^{7}$ BARTA (1998), ${ }^{8}$ BfNPI (Cservenka J.), ${ }^{9}$ SulYoK et al. (1998), 10Zöld Zala NGO (Óvári M.)

\begin{tabular}{|c|c|c|c|c|c|c|c|c|c|c|c|}
\hline & \multirow{2}{*}{ Harka } & \multirow{2}{*}{ Kőszeg } & \multirow{2}{*}{ Bakony } & \multirow{2}{*}{$\begin{array}{l}\text { Sümeg \& } \\
\text { Tapolca }\end{array}$} & \multicolumn{5}{|c|}{ Keszthelyi-hegység / Keszthely Hills } & \multicolumn{2}{|c|}{ Összes / Total } \\
\hline & & & & & 1 & 2 & 3 & 4 & 5 & 6 & \\
\hline 1992 & & & & & & & & & & 25 & \\
\hline 1993 & & & & & & & & & & 16 & \\
\hline 1994 & & & & & & & & & & 19 & \\
\hline 1995 & & & $2+100^{7}$ & & & $10^{9}$ & $2^{9}$ & & & 73 & \\
\hline 1996 & $2^{1}$ & & & $80^{9}$ & $6^{9}$ & $10^{9}$ & & & & 67 & \\
\hline 1997 & & & & & & & & & & 23 & \\
\hline 1998 & & & & 22 & & & & & & 27 & \\
\hline 1999 & & & & 57 & 3 & 1 & & & & 31 & \\
\hline 2000 & & & & & & & & & & 12 & \\
\hline 2001 & & & & & & & & & & 10 & \\
\hline 2002 & & & & 83 & & 4 & & & & 32 & \\
\hline 2003 & & & & 21 & & 9 & & & & 10 & \\
\hline 2004 & & $15^{5}$ & & & $0^{10}$ & $1^{10}$ & $0^{10}$ & & & 20 & \\
\hline 2005 & & & & & & & 1 & & & 55 & \\
\hline 2006 & $0(8)^{2}$ & & & & & & & & & 21 & \\
\hline 2007 & $0(9)^{2}$ & & $\begin{array}{c}32 \\
(161)^{8}\end{array}$ & $\begin{array}{c}201 \\
(436)^{8}\end{array}$ & & & & & & 21 & \\
\hline 2008 & $7(7)^{2}$ & $6^{6}$ & & 31 & & & & & & 36 & \\
\hline 2009 & $1(30)^{3}$ & $\begin{array}{c}40+? \\
(350)^{6}\end{array}$ & & 29 & & & & & & 25 & \\
\hline 2010 & & 33 & 11 & 25 & & & & & & 12 & 81 \\
\hline 2011 & & 18 & 12 & 49 & & 3 & & & & 29 & 111 \\
\hline 2012 & $0^{4}(48)$ & $2(618)$ & $3(386)$ & $\begin{array}{c}10 \\
(1058)\end{array}$ & & $0(11)$ & & & & $7(345)$ & 22 (2418) \\
\hline 2013 & $1^{4}(57)$ & $\begin{array}{c}50 \\
(873)\end{array}$ & $\begin{array}{c}41 \\
(607)\end{array}$ & $\begin{array}{c}63 \\
(2192)\end{array}$ & & $2(8)$ & & & & $\begin{array}{c}34 \\
(474)\end{array}$ & $191(4154)$ \\
\hline 2014 & $4^{4}(63)$ & $\begin{array}{c}178 \\
(939)\end{array}$ & $\begin{array}{c}85 \\
(516)\end{array}$ & $\begin{array}{c}214 \\
(2984)\end{array}$ & & $2(28)$ & & & & $\begin{array}{c}56 \\
(489)\end{array}$ & 539 (5019) \\
\hline 2015 & n.a. & 155 & 77 & 170 & & 3 & & 7 & & 73 & 478 \\
\hline 2016 & n.a. & 165 & 72 & 109 & & 1 & & $3(55)$ & $\begin{array}{c}12 \\
(36)\end{array}$ & 78 & 440 \\
\hline
\end{tabular}


Az 1990-es évek elején készült cönológiai felvételek szerint a pilikáni élőhelyen a $H$. adriaticum termőhelye erősen bolygatott. A populáció dolomit lejtősztyeppréten (Chrysopogono-Caricetum humilis) és annak degradált változatában élt, egyes példányok rontott bokorerdőben is előfordultak. A termőhelyre jellemző volt a természetes zavarástűrő növényfajok nagy aránya (egyes esetekben a $80 \%$-ot is elérte). A vizsgált terület növényei között nagy számban fordultak elő az eurázsiai és mediterrán (30\% és 20\% körüli) flóraelemek (SULYOK 1994).

1997-ben szűnt meg a katonai gyakorlatok okozta zavarás, amelynek nem várt hatásaként a tisztások, valamint az erdőszegélyben megmaradt keskeny fátlan sávok hamarosan sűrű bozótossá váltak. A másik veszélyforrást a megszaporodó lovasiskolák jelentették, mert ösvényeik közvetlenül a sallangvirág erdőszegélyben lévő tövei közt, vagy mellett vezettek. Palkó Sándor, természetvédelmi felügyelő az erdőből kihúzott faágak segítségével érte el, hogy a túralovasok ösvényt váltsanak. A telepített fenyves korábban ligetes foltjai is egyre több helyen megerősödtek, záródtak, így visszaszorultak a Himantoglossum tövek. A legnagyobb és tartósan magas egyedszámú csoportosulás a Pénzesgödörben és annak környezetében volt és van ma is, ez egykori dolomitnyerő gödör.

A Keszthelyi-hegységben 2011 után kezdődött fenyőusztulás a Pilikán-Szoroshadi út mentén telepített állományt is érintette. A fenyőállományokat 2013 és 2014 telén termelték ki. A kitermelés során a cserje-köpenyeket is megbontották, s az erdőszél ismét ligetesebbé vált. A tevékenység nyomán néhány sallangvirág tő is elpusztult, ennek ellenére a 20142016 években is igen gazdagon virágzott az állomány (1. ábra). A 25 éves adatsor jól mutatja, mennyire hullámzik a populáció egyedszáma. A fajnak kb. 10 évenként van egy vagy több kiemelkedően jó éve, a közben lévő időszakokban alacsonyabb egyedszám jellemezte a populációt.

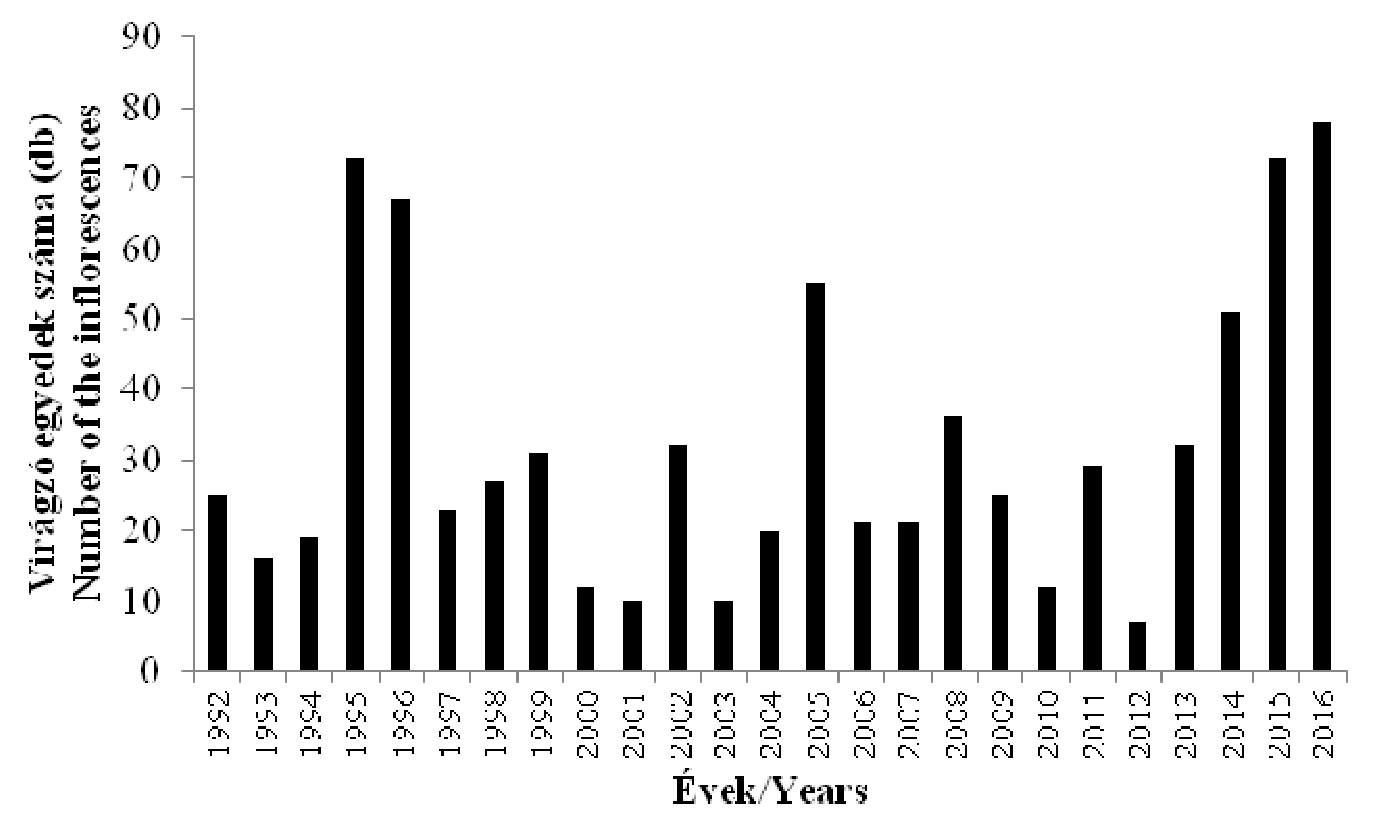

1. ábra. A virágzó tövek száma a Pilikán-Szoroshadi út mellett

Fig. 1. Number of flowering individuals in the largest population of Keszthely Hills

A faj fennmaradása biztosítottnak túnik a Pilikán-Szoroshadi út mellett, ám komoly fenyegetést jelent a bálványfa (Ailanthus altissima) inváziója. A bálványfa vegyszeres 
kezelése a sallangvirág élőhelyein - egyelőre - több foltban is hatékonynak bizonyult. A Pénzes-gödörbe viszont sok gyökérsarj nyomult be, ezek visszaszorítása sürgető feladat.

\section{További elófordulások a Keszthelyi-hegységben}

SULYOK et al. (1998) a Keszthelyi-hegységből pár virágzó töves előfordulásokat említ a rezi Várhegyről, a várvölgyi út mellől és a Négyszögü-hegyről. Reziben 1999-ben láttuk utoljára a faj egyedeit, a vár melletti bokorerdőben; a várvölgyi út mellett minden évben van néhány virágzat; a Négyszögü-hegyen pedig 2005-ben találtunk virágzó tövet. A várvölgyi út mentén lévő előfordulást gyakran a Fagyos-kereszthez kötik, de ennél jóval északabbra van, mint azt SZODFRIDT (1959) is írja. Itt egy részben anyagnyerés miatt bolygatott, másodlagosan kialakult gyep-bokorerdő komplexben, részben az útpadkán nőnek az egyedek.

Gyenesdiáson, 2015-ben, a Tüskés-lap aljában Pacsai Bálint talált 7 virágzó példányt (Pacsai ex verb.), ami új előfordulás. 2016 tavaszán 55 tőlevélrózsát számoltunk itt, de a bolygatott, gyomos élőhelyen csak három tő virágzott. 2016 márciusában SzODFRIDT 1959-es adatát sikerült megerősíteni: a Bottyán-háton (Cserszegtomaj) néhány előző évi kórót és 36 tőlevélrózsát találtunk, melyből 12 virágzat fejlődött.

\section{Sümeg-Tapolcai-hát}

A legnagyobb hazai populáció, a sümegi és a nyirádi út mellett 4, ill. $2 \mathrm{~km}$ hosszan található (SULYOK et al. 1998). Valószínűleg ezen a lelőhelyen készült VAJDA \& VAJDA (1930) fényképe (1930. június 8., „Bakonyhegység Tapolcától északra”) és VAJDA (1956) fényképe: „Bakony, Nyirádi erdőben, májusban". Főleg a kaszált útszegélyben jelennek meg magányosan vagy kisebb csoportokban a példányok. A tövek ma a nyirádi út azon szakaszán találhatók, ahol ötven évvel ezelőtt még gyepterületek, bokrokkal tarkított gyepek kapcsolódtak az úthoz (3. ábra - Elektronikus melléklet).

Nagyobb egyedszámban fordul elő a Sümeg és Tapolca közti „erdei út” mellett, s különösen sok van az Úrbéri Erdészház udvarán, az előtte lévő gyepben és útszegélyen (4. ábra Elektronikus melléklet). Az utat kísérő bokrok alatt és azok szegélyében is megtalálható, nemcsak a gyepben. Sok kis vegetatív egyed nő veresgyürü som (Cornus sanguinea) és kökény (Prunus spinosa) bokrok alatt. Ezek a cserjék sűrü lombja miatt nem kapnak elegendő fényt, nem tudnak nőni, lassan kifogynak tartalékaik és elpusztulnak. A virágzó példányok jellemzően a fásszárú-gyep szegélyekben találhatóak.

2013-ban a Sümeg-Tapolcai-háton összesen 2193 tőlevélrózsát találtunk, melyből 1458 $(66,5 \%)$ nőtt közvetlenül az út mentén (sümegi út: 1380 példány; nyirádi út: 78 tő), és csak az állomány kb. harmada volt az úttól 3 méternél távolabbi területeken.

A mintegy 1000-2000 vegetatív egyedből a megfigyelt években évjárattól függően a virágzó egyedek száma 10 (2012) és 214 (2014) között változott (1. táblázat).

A Balaton-felvidéki Nemzeti Park Igazgatóság munkatársai gondot fordítanak rá, hogy a sallangvirágos szakaszokon az útszélek kaszálása csak a termésérést követően történjen meg. Az erdészház üzemeltetôi is kiemelten figyelnek a sallangvirágok megóvására, csak virágzás és termésérlelés után kaszálják a gyepet.

A példányok az út mellett hosszan, többféle kitettségben és termőhelyen találhatóak. Így túl azon, hogy ez a legnagyobb állomány, a változatos, egymástól független mikro-élőhelyek tartós fennmaradást tesznek lehetővé. Szárazabb években az árnyasabb, nyirkosabb élőhelyeken lévő példányok virágoznak, míg a nedvesebb években a száraz termőhelyeken is nagyobb a virágzó tövek aránya. 


\section{Köszegi-hegység}

Waisbecker Antaltól $9 \mathrm{db}$ H. adriaticum lapot őriznek hazai gyújtemények (6 lap a BP Herbarium Carpato-Pannonicum, 2 lap a Savaria Múzeum, 1 lap az ELTE Füvészkert gyújteményében), melyeket Kőszegen gyűjtött 1891. 07. 02. és 1902. 06. 15. között. Lelőhelyként a „Meszes-völgy”, „Kalkgraben dülö", „hegyi rét”, „hegyi kaszáló, ,hegyi füvesben, bokros helyen” szerepel az egyes példányok mellett. „Kalkgraben fölső részén, a kőfejtő körül” megjelöléssel Freh Alfonztól is van egy lap, ő 1884. 06. 18-án gyűjtötte a növényt (SAMU). A város szőlőhegyének, a Szabó-hegynek lejtőin, a Meszes-völgyben, magántelkeken találták meg a kipusztultnak gondolt állományt 2004-ben (KIRÁLY \& MESTERHÁZY 2006).

A Meszes-völgyre néző oldalakon az 1857-es kataszteri térkép tanúsága szerint szinte minden művelhető területen szőlőt termesztettek, a kevés gyepterület mellett csak a sziklákkal, meredek letörésekkel tarkított részeken maradtak fenn kis erdőfoltok (5. ábra - Elektronikus melléklet).

Az 1970-es évekre a szőlőként való művelés már kisebb jelentőségű, $s$ a rétek becserjésedése is előrehaladt. Az egykori gyümölcsös és szőlő helyén lévő magánkertben, korábban kaszált, ma fünyírózott aljú gyümölcsösben, illetve gyepben élnek a sallangvirágok (5. ábrán 1 és 3a jelü területek - Elektronikus melléklet). 2015 nyarán, ezen az egy telken 94 virágzatot számoltunk, 2016-ban pedig 136-ot, jórészt annak köszönhetően, hogy a tulajdonos házaspár igen nagy gondossággal és odafigyeléssel kerüli a fokozottan védett növények lefünyírózását. Érdekes, hogy a legtöbb példány az egykori szőlőparcella helyén, egészen kis területen van.

Ugyancsak szőlő helyén nőnek a sallangvirágok a jelenlegi Ciklámen üdülő területén, másodlagosan kialakult, magaskórósodó franciaperjés gyepben (5. ábrán 3b jelű rész - Elektronikus melléklet). Ezt a parcellát 1988-ig művelték, itt 2012 tavaszán 111 tőlevélrózsát számoltunk. A terület évente egyszer kerül lekaszálásra, de felverődött benne a szeder és gyakran a sallangvirágok ki sem látszanak a buja növényzetből.

A fentebb említett kert és a Ciklámen üdülő között egy sziklákkal, letörésekkel szabdalt, korábban gyepként hasznosított területen, mára teljesen becserjésedett részen 2013-ban találtunk tőleveleket (5. ábrán 2 számmal jelölt terület- Elektronikus melléklet). Az itt lévő tőlevélrózsákból 2013-ban 12 virágzat fejlődött, ezek virágzatonkénti virágszáma nem különbözött a gyepekben lévő növényekétől (átlagos virágszám a fásszárúak alatt: 39,9 db, gyepen: 33,8 db) viszont a termésképzési siker igen. Az árnyékban élő 12 egyed 479 virágából mindösszesen 12 toktermés képződött, ami 2,5\%-os termésképzési siker, míg a naposabb helyen élő 38 növény 1285 virága összesen 709 toktermést hozott, ami viszont 55,2\%os termésképzési arány. Az árnyékban élő tövek esetében a virágzatonkénti virágszám és a tokszám között nem volt kapcsolat, míg a nem árnyékban élő egyedeknél minél nagyobb volt a virágszám, annál több tok képződött a virágzatban (SÁNDOR 2013).

A Kőszegi-hegységben nőttek a legmagasabbra a virágzatok, az átlagérték $69,9 \mathrm{~cm}, \mathrm{~s}$ itt mértük az eddigi legnagyobb értéket, $115 \mathrm{~cm}$-t is. A virágzatonkénti virágszám is magas, 35,6 $\mathrm{db}$, az átlagos termésképzési arány 38,3\%.

\section{Bakony}

Nagytevel és Bakonyjákó községhatárában, a Bakony-ér menti oldalakon, illetve felette a fennsíkon találhatók sallangvirágok, többé-kevésbé körbehatárolható foltokban. A szomszédos településről volt a fajnak régebbi adta, Jávorka Sándor és Májer Antal Ugod alatt, „a talgunyhói öreg cseres felé, füves lejtőn" gyüjtött H. adriaticum-ot 1951. 07. 14-én (BP).

A sallangvirágos területek a 18. század második felében szőlővel borítottak voltak (6. ábra - Elektronikus melléklet). A szőlők mellett gyümölcsösök, gyepek és erdőfoltok 
váltakoztak a változatos felszínű tájban. A száz évvel később, a 19. század közepén készült kataszteri felmérés pontosan visszatükrözi a terület adottságainak tájhasználati leképezését: erdők találhatók a meredek letöréseken, illetve közvetlenül a letörések alatt, szőlő a lejtőkön, s gyepsávok közöttük, illetve a lapos, homokos részeken, a völgy aljában (6. ábra Elektronikus melléklet).

A zirci apátság nyugat-bakonyi birtokainak központja Tevel volt, és a ciszterciek telepítették be németekkel a falut a 18. században. A ciszerciek fejlett majorsági gazdálkodást folytattak a faluhoz közeli területeken, a falu lakossága a környezeti feltételekhez igazodva művelte szőlőnek, gyümölcsösnek, kaszálónak a településtől távol eső, vékony termőrétegű területeket. Drasztikus tájhasználat változást hozott a II. világháború és az azt követő kitelepítések. A németek helyére telepített új lakosok nem művelték tovább a település távoli határainak kis termőképességű, köves területeit. A szocialista nagyüzemi gazdálkodás során felhagytak a kisparcellás szőlők és gyümölcsösök művelésével, a tájhasználat homogenizálódott, birkalegelőként hasznosították a sovány gyepeket. Az 1963ban készült légifotó északi részén nagy juhhodályok láthatók, a korábbi kisparcellás szőlőművelésre a jól kivehető obalák (a szőlőparcellák szélére rakott alacsony kőfalak, melyekre rendszerint cserjék települnek, s a cserjesávok jól kirajzolják az egykori parcellahatárokat a légifotókon is) emlékeztetnek, illetve kisebb foltokban fennmaradt gyepes területek, mint az 1-sel jelölt domb, melyen a korábbi szőlő- és gyümölcsművelés nyomai még láthatók (6. ábra - Elektronikus melléklet). A fennsík és közvetlen környékének felhagyását az is magyarázza, hogy az 1960-as évektől 1990-ig a fennsík nyugati szélére települt egy szovjet katonai bázis, melynek ez a rész is katonai gyakorlóterülete volt. A szovjet katonák távozása után privatizálták a területet, ám a használat nem vált rendszeressé, a cserjésedés tovább erősödött. 2012 óta több évben is történt cserjezúzás a fennsíkon és a lejtőn is.

A sallangvirágok kis gyepes foltokban, bokrok alatt és azok szegélyében nőnek. A cserjeirtások során az addig teljes árnyékban vegetáló tőlevélrózsák napfényre kerülnek, $\mathrm{s}$ ha van elegendő csapadék tavasszal, a vékony termőréteg nem szárad ki túl hosszan, akkor gazdag virágzást és igen jó termékenyülést tapasztaltunk. Száraz télvégi és tavaszi időjárásban viszont besülnek a virágzatok.

A megfigyelt évek alatt 3 (2012) és 85 (2014) között változott a virágzó egyedek száma, a tőlevélrózsák száma 400-600 körüli. A megmért 222 virágzat átlagosan 36,6 db virágából 20,2 db tok képződött, a termésképzési arány átlagos értéke az országban itt a legmagasabb: $54,4 \%$. Ennek oka lehet az is, hogy a fennsíkon a sallangvirágok virágzási idején gyakran vannak vándorméhészetek, melyek a környező akácosok miatt települnek oda. A házi méhek gyakori megporzói a sallangvirágoknak is (BIRó et al. 2015).

\section{Harka}

A Harkai-kúpon, jelenleg is szőlőkkel közrezárva, egykori szőlők helyén található a faj kis állománya, erősen becserjésedett foltokban (7. ábra - Elektronikus melléklet). Az egykori szőlőparcellákra utalnak a sűrű cserjésben fellelhető obalák (rakott kőfalak).

2012 tavaszán, egy kisebb folton levágták a cserjéket a Fertő-Hanság Nemzeti Park munkatársai, majd a következő években újabb foltokat nyitottak meg a sallangvirágok felett. Ennek köszönhetően minden évben van néhány virágzó tő (Takács ex verb.).

\section{Összefoglalás, kitekintés}

A H. adriaticum-nak négy nagyobb állományát ismerjük Magyarországon. A Sümeg-Tapolcaiháton van a legnagyobb, nagyságban ezt követi a kőszegi Szabó-hegyen lévő populáció, míg a 
Bakonyban és a Keszthely-hegységben kb. azonos méretű állományok találhatók. Herbáriumi gyűjteményekben összesen harminchárom herbáriumi lap ismert, melyen hazánk jelenlegi területéről származó $H$. adriaticum példányok vannak. A jelenleg ismert előfordulási adatok közé két herbáriumi adat nem illeszkedik: Egerben 1816-ban Láng Adolf Ferenc, 1870. 06. 06-án Vrabélyi Márton gyűjtötte a növényt (BP) (SULYOK et al. 1998), míg Aszódon 1928. 06. 15-én Rigler József (BRA) (TAKÁCs et al. 2016). Van lap Badacsonyból is, egy ismeretlen gyüjtőtől származó 1938. 07. 01-ei példány (DE), innen sincs recens adata a növénynek.

A hazai állománynagyság évjárattól függően kb. 2500-5000 tő, melyek közül évente 22539 tő virágzott. A faj jellemző élőhelyei az útszélek és a felhagyott szőlők (a három, aktuálisan megerősítetlen herbáriumi gyűjtőhely térségében is jellemző a szőlőművelés). „Auf steinigen, buschigen Hügeln, besonders in der Nähe von Weingärten” azaz „Köves, bokros dombokon, különösen szőlók közelében" írta már 1866-ban August NEILREICH (1866: 66). Minden nagyobb előfordulási helyén kimutatható az egykori szőlőművelés (kivéve a SümegTapolcai-háton lévő, zömében útszéli, de szintén bolygatott termőhelyű állományt). Külföldi tapasztalatok alapján kijelenthető, hogy ez nem magyarországi sajátosság, a faj állományait Horvátországban, Szlovéniában, Olaszországban és Szlovákiában is láttuk már felhagyott szőlőhegyeken vagy művelt szőlők közelében. Ugyancsak általános az útszéli élőhely is (Horvátország, Olaszország).

Vajda Ernő így jellemezte a faj előfordulásait: „sehol sem él tömegben, mindenütt csak szálanként lehet találni” (1956: 27.). A szálanként való előfordulásra a „szatelit előfordulás” kifejezést használják abban az esetben, amikor csak egyetlen évben van egy virágzó tő, ami a következő években már nem jön elő, vagy legalábbis nem virágzik (CAREY et al. 2002). Ilyen előfordulásra nyújtanak példát a zalai felbukkanások, bár az egyik tő többször is virágzott (ÓVÁRI 2017). Lájer Konrád a Rendeki-hegyen, Szilaj Rezső a Sipos-toroknál, magam pedig a Négyszögű-hegy (mindkettő Keszthelyi-hegység) két pontján találtam egy-egy virágzó tövet. A Négyszögü-hegyen éveken át figyeltem a lelőhelyeket, ezek az egyedek nem jöttek elő többet. Ez a megjelenési forma a közelrokon H. hircinum-ra (CAREY et al. 2002) és más, ritkább orchideafajokra is jellemző.

A gyep-karsztbokorerdő mozaik tekinthető a faj elsődleges élőhelyének, ahol leginkább szálanként található. A másodlagos élóhelyeken azonban Magyarországon is tapasztalhattunk nagy egyedszámokat, például a kivételesen jó évnek számító 2016-ban. Kőszegen, felhagyott szőlő helyén kialakult gyepben $2 \times 2$ m-es kvadrátban 23 virágzó tövet számoltunk. A faj elterjedési területének középső részein gyakoribbak a nagy állományok, Horvátországban és Olaszországban is rábukkantunk nagy létszámú, viszonylag kis területen előforduló populációkra. Szlovéniában 1980 után a fajnak számos új lelőhelyét találták meg az ország középső részein, s igen sok új előfordulást közöltek az Isztriai-félszigetről és a Halozei borvidékről (TRČAK et al. 2006). Mivel a H. adriaticum a klímaváltozásra kedvezően reagál (MolNÁR V. et al. 2012), lehetséges, hogy a szlovéniai új előfordulások már a faj terjedésének tudhatóak be. A H. hircinum angliai terjedéséről már bizonyították, hogy annak oka a sallangvirág számára kedvező klímaváltozás (CAREY et al. 2002, VAN DER MEER et al. 2016).

Az adriai sallangvirág állományainak szüksége van arra, hogy ne záródjon felettük a cserjeszint, azonban a cserjék alatt is hosszan túlélnek a tőlevelek. A legjelentősebb veszélyeztető tényező a teljes becserjésedés, de a faj felhagyott szőlőhegyeken, ősgyepekben és ligetes erdőkben való megjelenése, valamint a klímaváltozásra adott pozitív válasza azt erősíti, hogy képes új élőhelyeket meghódítani. Ezt igazolja, hogy szinte évente kerülnek elő új hazai előfordulásai. 


\section{Köszönetnyilvánítás}

Köszönöm Almádi Lászlónak, hogy 1992-ben felhívta figyelmem a fajra és egy állományát megmutatta a Pénzes-gödörnél. A kőszegi lelőhely megismerését Emődy Wáman-Zoltánnak, a harkait Takács Gábornak, a bakonyit Zábrák Károlynak köszönöm. Az elmúlt 6 évben a terepmunkában a Pannon Egyetem Georgikon Karának természetvédelmi mérnök hallgatói segítettek. Egy vagy néhány terepnapra számos hallgatót magammal vihettem, de voltak, akik éveken át segítettek: Biró Éva, Gerner Gerda, Nagy Timea, Simon Zsófia, Németh Anna, Molnár Katalin és Sándor Zsuzsanna. Mindannyiuknak hálás vagyok, köszönöm munkájukat! A Magyarországi Orchideák Herbáriumi Adatbázisából Nagy Timea válogatta ki számomra a H. adriaticum lapokat. Köszönet illeti a kézirat lektorálásáért Vidéki Róbertet, valamint Molnár V. Attilát, aki ezen túl az Elektronikus melléklet ábráinak szerkesztésében is segített, $\mathrm{s}$ értékes forrásokat bocsátott rendelkezésemre.

\section{Irodalom}

BARTA Z. (1998): Himantoglossum adriaticum Baumann Nagytevel határában, a Bakonyban. - Kitaibelia $3(2): 371$.

Bateman R. M., Molnár V. A. \& SRAmkó G. (2017): In situ morphometric survey elucidates the evolutionary systematics of the Eurasian Himantoglossum clade (Orchidaceae: Orchidinae). - PeerJ 5: e2893.

BAUER N. (2007): Florisztikai adatok a Bakonyból és a Bakonyaljáról III. - Kitaibelia 12 (1): 41-51.

BAUMANN H. (1978): Himantoglossum adriaticum Baumann - eine bislang übersehene Riemenzunge aus dem zentralen nördlichen Mittelmeergebiet. - Orchidee 29: 165-172.

BiRó É., BóDIS J., NAGY T., TöKÖLYI J. \& MoLNÁR V. A. (2015): Honeybee (Apis mellifera) mediated increased reproductive success of a rare deceptive orchid. - Applied Ecology and Environmental Research 13 (1): 181-192.

CAREy P. D., FARREll L. \& STEWART N. F. (2002): The sudden increase in the abundance of Himantoglossum hircinum in England in the past decade and what has caused it. - In: KindLMAnN P., Willems J. \& Whigham D. F. (eds), Trends and fluctuations and underlying mechanisms in terrestrial orchid populations. Backhuys Publishers, Leiden, pp. 187-208.

IUCN (2001): IUCN Red List Categories and Criteria: Version 3.1. IUCN Species Survival Commission. IUCN, Gland, Switzerland and Cambridge, UK. ii +30 pp.

KirÁLY G. \& MESTERHÁzy A. (2005): Az adriai sallangvirág (Himantoglossum adriaticum H. BAumANN) újrafelfededezése a Kőszegi-hegységben. - Kitaibelia 10: 197.

KIRÁLY G. (szerk.) (2007): Vörös Lista. A magyarországi edényes flóra veszélyeztetett fajai. - Saját kiadás, Sopron, 73 pp.

MoLNÁR V. A., SULYOK J. \& VIDÉKI R. (1995): Vadon élő orchideák. - Kossuth Könyvkiadó, Budapest.

Molnár V. A., TöKölyi J., VÉGVÁri Zs., SRAmKó G., Sulyok J. \& BARTA Z. (2012): Pollination mode predicts phenological response to climate change in terrestrial orchids: a case study from central Europe. Journal of Ecology 100: 1141-1152.

NeILREICH A. (1866): Aufzählung der in Ungarn und Slavonien bisher beobachteten Gefässpflanzen. Braumüller, Wien.

NÉMETH F. (1989): Növényvilág. Száras növények. - In: RAKOnCZAY Z. (szerk.), Vörös Könyv. Akadémiai Kiadó, Budapest, pp. 263-321.

ÓvÁRI M. (2017): A Himantoglossum adriaticum Baumann a Kelet-Zalai-dombságban. - Kitaibelia 22 (2): in press.

SÁNDOR Zs. (2013): A Himantoglossum adriaticum szaporodásbiológiai vizsgálata. - Szakdolgozat, Keszthely, $34 \mathrm{pp}$.

Sramkó G., Molnár V. A., Hawkins J. A. \& Bateman R. M. (2014): Molecular phylogeny and evolutionary history of the Eurasiatic orchid genus Himantoglossum s.l. (Orchidaceae). - Annals of Botany 114 (8): 1609-1626. 
SulyoK J. (1994): A Himantoglossum adriaticum Baumann és a Himantoglossum caprinum (M. Bieb.) Sprengel elfordulása hazánkban, és cönológia viszonyaik. - Diplomadolgozat, Debrecen.

SULYOK J., VIDÉKI R. \& MoLNÁR V. A. (1998): Adatok a magyarországi Himantoglossum-fajok ismeretéhez. Kitaibelia 3 (2): 223-229.

SzABó I. (1987): A Keszthelyi-hegység növényvilágának kutatása. - A Bakony Természettudományi Múzeum Közleményei 6: 77-98.

SzodFridT I. (1959): Új adatok a Keszthelyi-hegység és a Dél-Bakony flórájához. - Botanikai Közlemények 48 (1-2): 75-76.

TAKÁcs A., Baráth K., CSiky J., Csikyné R. É., Király G., NAGy T., PAPP V., SChmidt D., TAMÁsi B. \& Barina Z. (2016): Taxonomical and chorological notes 3 (28-37). - Studia botanica hungarica 47 (2): 345-357.

TímÁR G. (1997): Új adatok a Soproni-hegység flórájához. - Kitaibelia 2 (2): 245-247.

TRČAK B., ERJAVEC D., JAKOPIČ M. \& JAVORIČ A. (2006): Popis jadranske smrdljive kukavice (Himantoglossum adriaticum) s predlogom conacije Natura 2000 območja "Haloze - vinorodne" (SI3000117).

van der MeER S., JaCQuemyn H., CAREY P. D. \& Jongejans E. (2016): Recent range expansion of a terrestrial orchid corresponds with climate-driven variation in its population dynamics. - Oecologia 181 (2): 435-448.

VAJDA E. \& VAJDA L. (1930): Flora Photographica Hungariae. - Budapest.

VAJDA E. (1956): A magyar növényvilág képeskönyve. - Művelt Nép, Budapest.

\section{Hivatkozott világháló oldalak}

[1] A Habsburg Birodalom első katonai felmérésének digitalizált térképei / Digitized map sheets of the $1^{\text {st }}$ Military Survey of the Austrian Empire http://mapire.eu/en/map/firstsurvey/ (Hozzáférés: 2016. 12.15.)

[2] A Habsburg Birodalom második katonai felmérésének digitalizált térképei / Digitized map sheets of the $2^{\text {nd }}$ Military Survey of the Austrian Empire http://mapire.eu/en/map/secondsurvey/ (Hozzáférés: 2016. 12. 15.)

[3] A Magyar Királyság kataszteri térképei (19. század) / Digitized sheets of cadastral map of Hungarian Kingdom (XIX. century)

http://mapire.eu/hu/map/cadastral/ (Hozzáférés: 2016. 12.15.)

[4] http://www.fentrol.hu/hu, Budapest Főváros Kormányhivatala (Hozzáférés: 2016. 12. 15.)

[5] https://www.google.com/earth/ (Hozzáférés: 2016. 12.15.)

Beérkezett: 2016. 12. 22. • Elfogadva: 2017. 04. 20. 
BóDIS J. (2016): Az adriai sallangvirág (Himantoglossum adriaticum) magyarországi állományai és lelőhelyeik tájhasználatának története / Hungarian localities of Himantoglossum adriaticum and its landuse history. - Kitaibelia 22 (1): 84-94.

(DOI: 10.17542/kit.22.84)

\section{Elektronikus melléklet - Electronic Appendix 1.}

Keszthelyi-hegység: Pilikán-Szoroshadi út
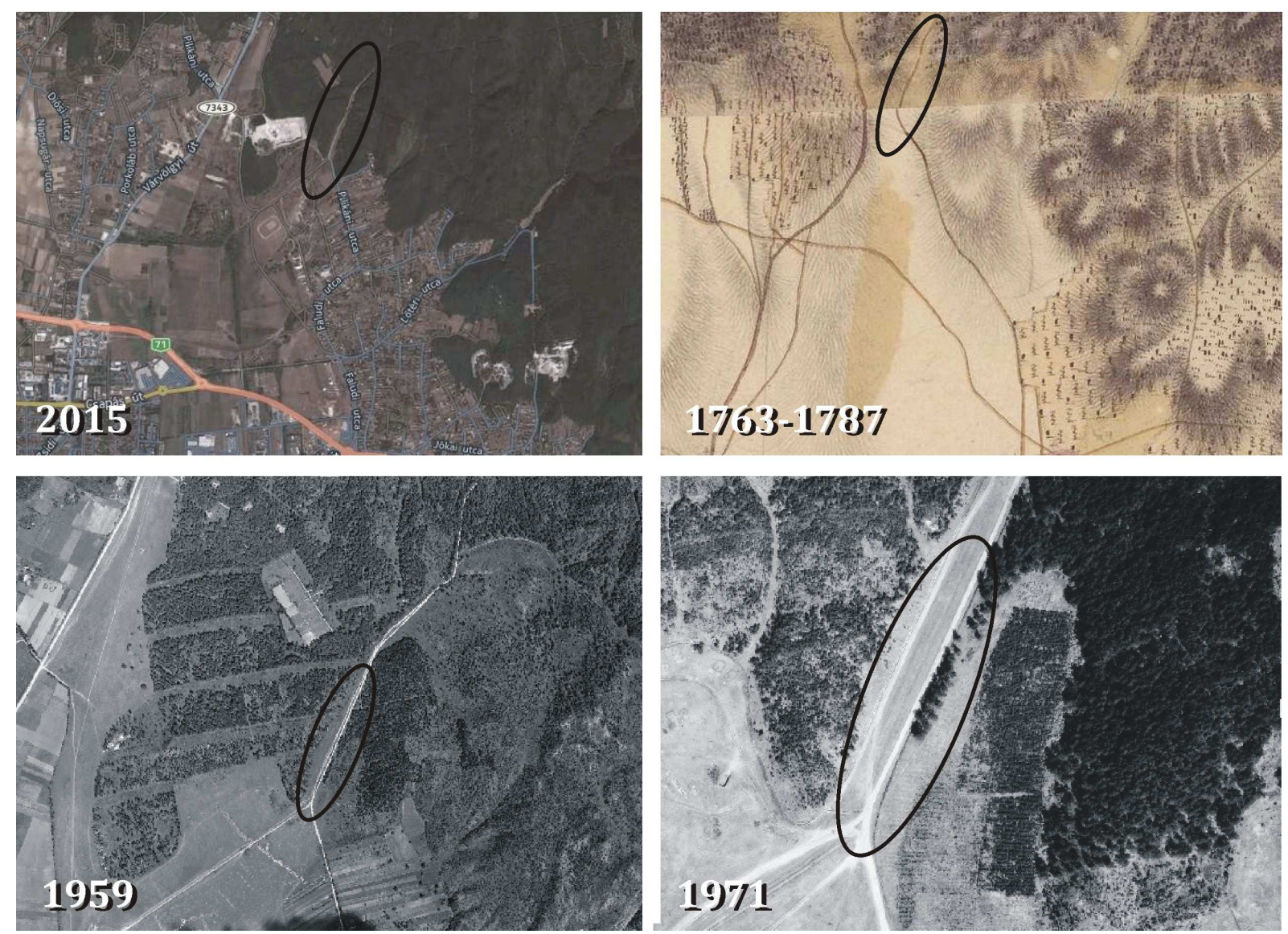

2. ábra. A Keszthelyi-hegység legnagyobb sallangvirág állományának déli részét jelölik az ellipszisek. Az erdők északabbra kezdődtek az I. Katonai Felmérés [1] idején, mint napjainkban, a településhez közelebb eső dombok legelők voltak, a környéken sok szőlőhegy volt (1784). Az 1959-ben készült légifotón [4] jól látszik, hogy a dolomitrögökre, az egykori legelők helyére fekete fenyőt ültettek. Az 1971-es légifotón [4] a különböző korú fenyőültetvények és a homokkal bélelt völgyaljra telepített tölgyes (az úttól keletre) is jól kivehető.

Fig. 2. Ellipses show the south part of the largest Adriatic lizard orchid population in Keszthely Hills. Grasslands were larger during the First Military Survey (1784) than today. There were pastures on the dolomite hills nearby the settlements and large areas were used as vineyards [1]. On the aerial photo of 1959, black pine forest can be seen on the area of earlier grasslands [4]. On the aerial photo of the same area from 1971 [4]. 
Sümeg-Tapolcai-hát: nyirádi út és Úrbéri Erdészház

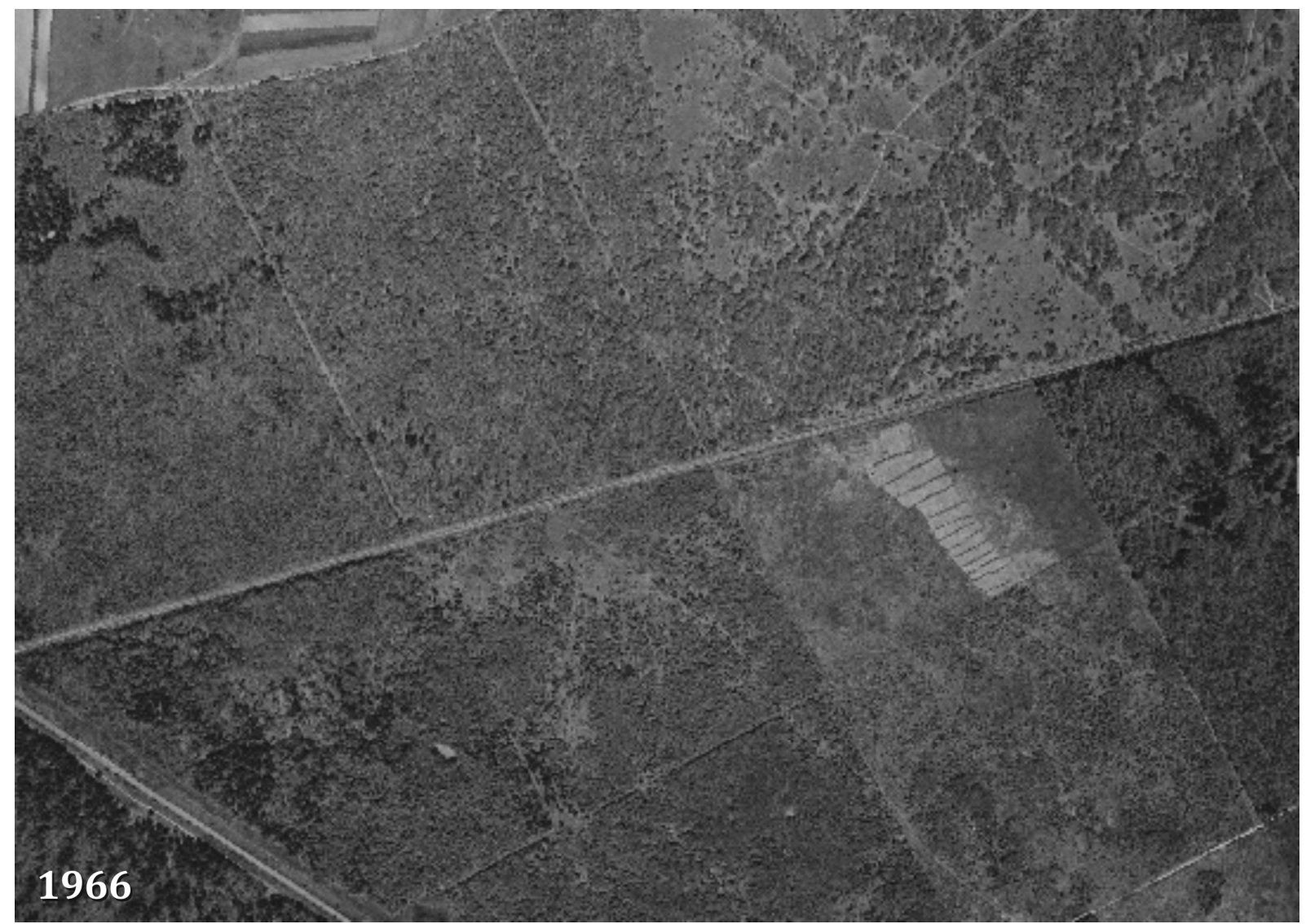

3. ábra. 1966: a nyirádi út azon szakasza, ahol ma a sallangvirágok nőnek, láthatóan napsütötte, ligetes erdők és fiatal ültetvények által határolt [4].

Fig. 3. 1966: the part of the road to Nyirád, where lizard orchids are growing today with sunny grasslands and young plantations on both sides [4].
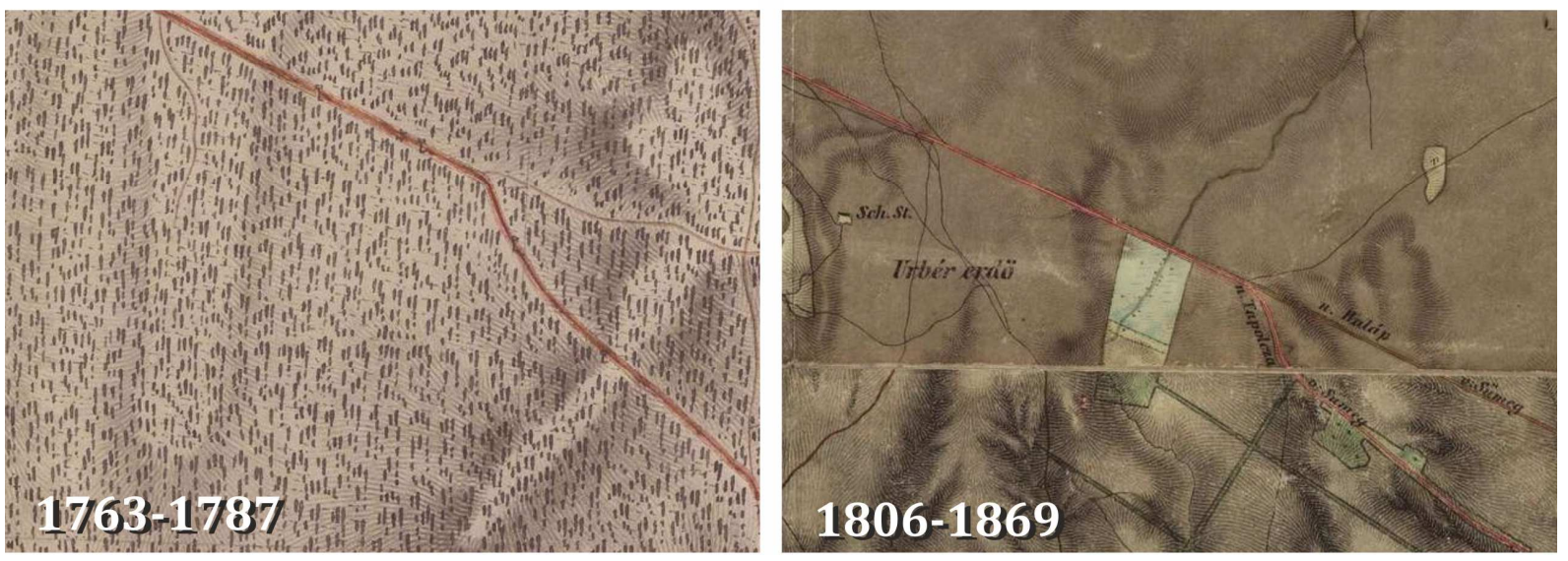

4. ábra. A Sümeg és Tapolca közti „erdei út”, valóban sűrű erdőt vágott át (balra, I. Katonai Felmérés) [1], melyben a II. Katonai Felmérés idején (jobbra) [2] már jelölik a későbbi erdészháznak is helyet adó tisztást.

Fig. 4. The local name of the road between Sümeg and Tapolca is 'forest road', which really run through dense forest in the time of the First Military Survey (left) [1], The Second Military Survey (right) signed the clearing which is an important terrain of the lizard orchids today [2]. 


\section{Kőszegi-hegység: Szabó-hegy}
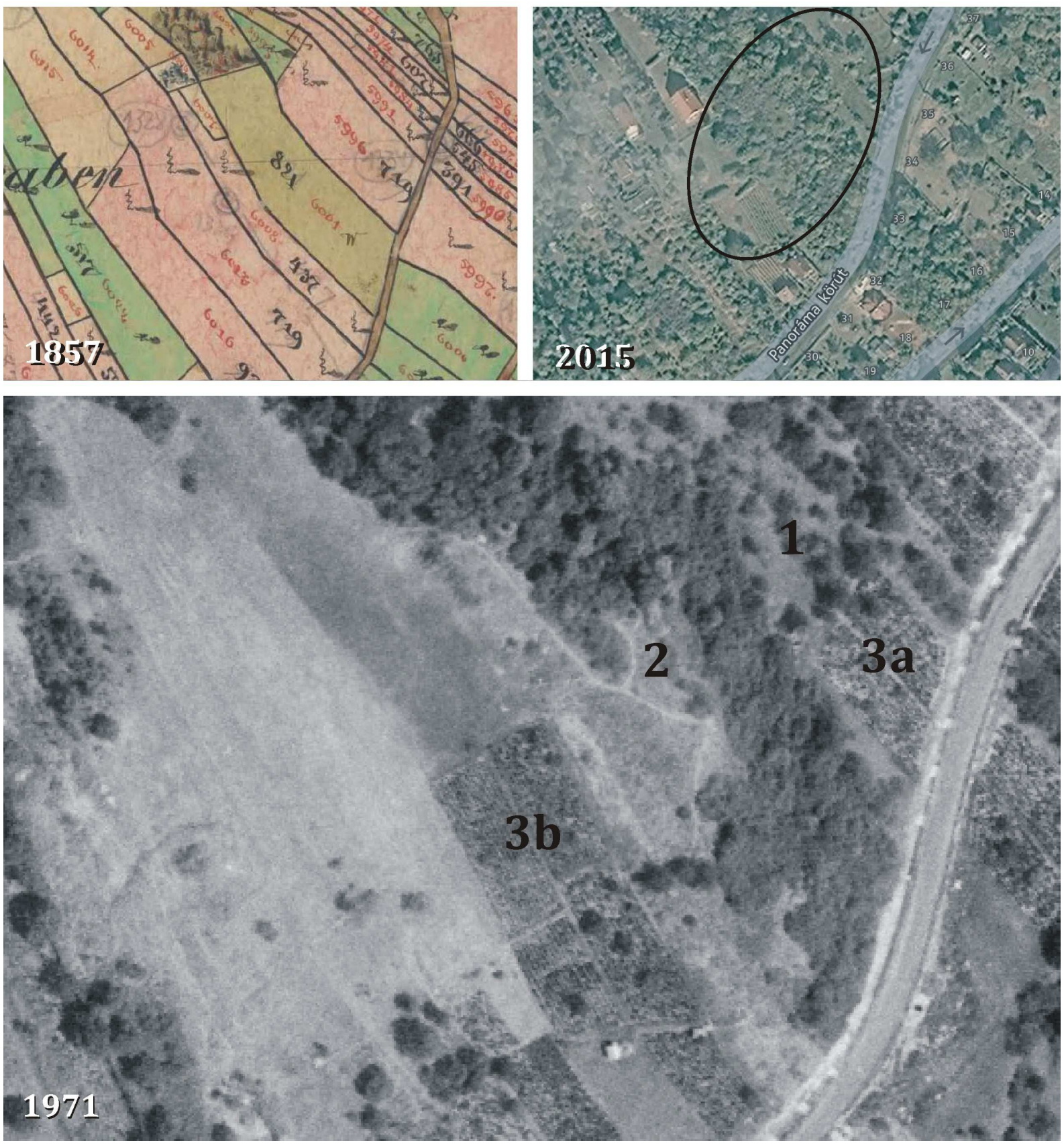

5. ábra. A kőszegi Szabó-hegy a város egykori szőlőhegye. Fent, bal oldalon, az 1857-es kataszteri térképen [3] (barnás)zölddel a gyepek, rózsaszínnel a szőlők, sárgás színnel a szőlőparcellák feletti sík, szántóföldként művelhető területek. A déli lejtőkön a sziklákkal, meredek letörésekkel tarkított parcellák maradtak gyep művelési ágban. A jobb oldali légifotó a jelenlegi helyzetet [4], s a faj előfordulási területét mutatja. Az 1971-ben készült légifotón [4] a számok a mostani sallangvirág előfordulásokat mutatják, aszerint, hogy milyen élőhely volt a fotó készítése idején a terület. 1: gyümölcsöskert (most is az), 2: gyep (most sűrű cserjés), 3: szőlő (3a: most nyírt gyep, 3b: kaszált magaskórós).

Fig. 5. The Szabó Hill was the vineyard of Kőszeg. Above to the left on the cadastral map (1857) [3] the grasslands are green, vine parcels are pink, flat, arable fields are yellowish. On the south slopes only the rocky areas remained grasslands. Above to the right the aerial map [4] shows the recent habitat of the lizard orchid. On the aerial photo from 1971 [4] the numbers show the usage of the recent localities in that time. 1: orchard (same now), 2: grassland (now dense scrub), 3: grape parcel (3a: now grassland, regularly mowed; 3b: now tall-herb vegetation, rarely mowed). 


\section{Bakony: Nagytevel}
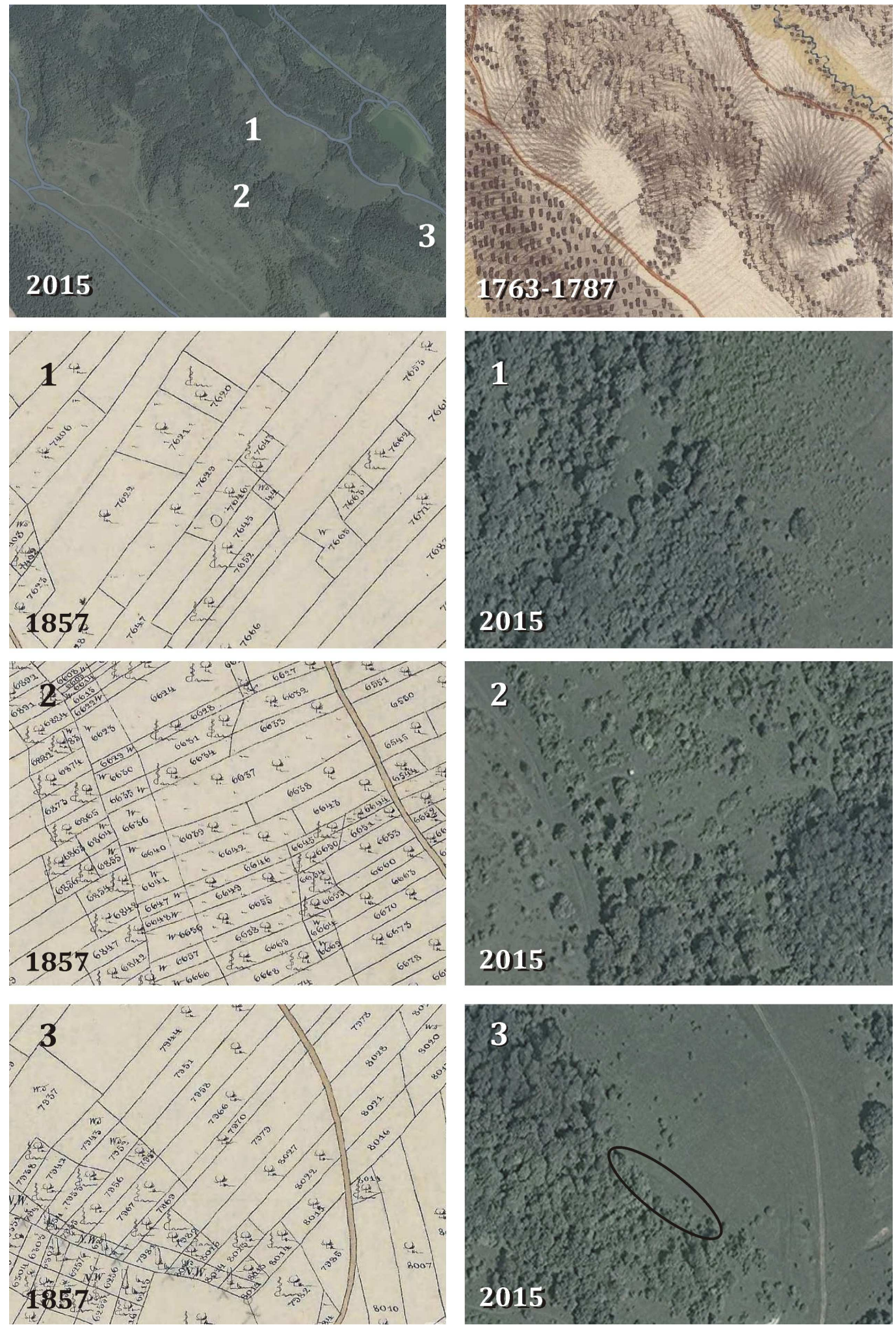

6. ábra. A nagyteveli (Bakony) területen ott találjuk a sallangvirágokat [5], ahol az I. Katonai Felmérés (1783) szőlőket jelöl [1]. A bal felső műhold fotón lévő számok az alatta lévő ábrákon bemutatott részletek helyét jelölik. A kataszteri felmérések térképlapjai [3] megerősítik, hogy a sallangvirágok egykori szőlőparcellák helyén nőnek (a 3. részterületen ellipszissel jelölve a mai élőhely, mely csakis a szőlőparlagok helyére korlátozódik). A parcellákat egykor elválasztó kőrakások (obalák) vonalát cserjesávok rajzolják ki a mühold felvételeken.

Fig. 6. The lizard orchids are growing on Nagytevel (Bakony Hills) where vineyards were during the First Military Survey (1783) [1]. The numbers on the satellite images (above, left) [5] mark the localities of the figures below. The sheets of the cadastral map [3] also indicate vine parcels on the recent localities of $H$. adriaticum. Ellipse reflects the exact location of the lizard orchid. The line of shrubs illustrates the late borderlines of the parcels. 


\section{Harkai-kúp}
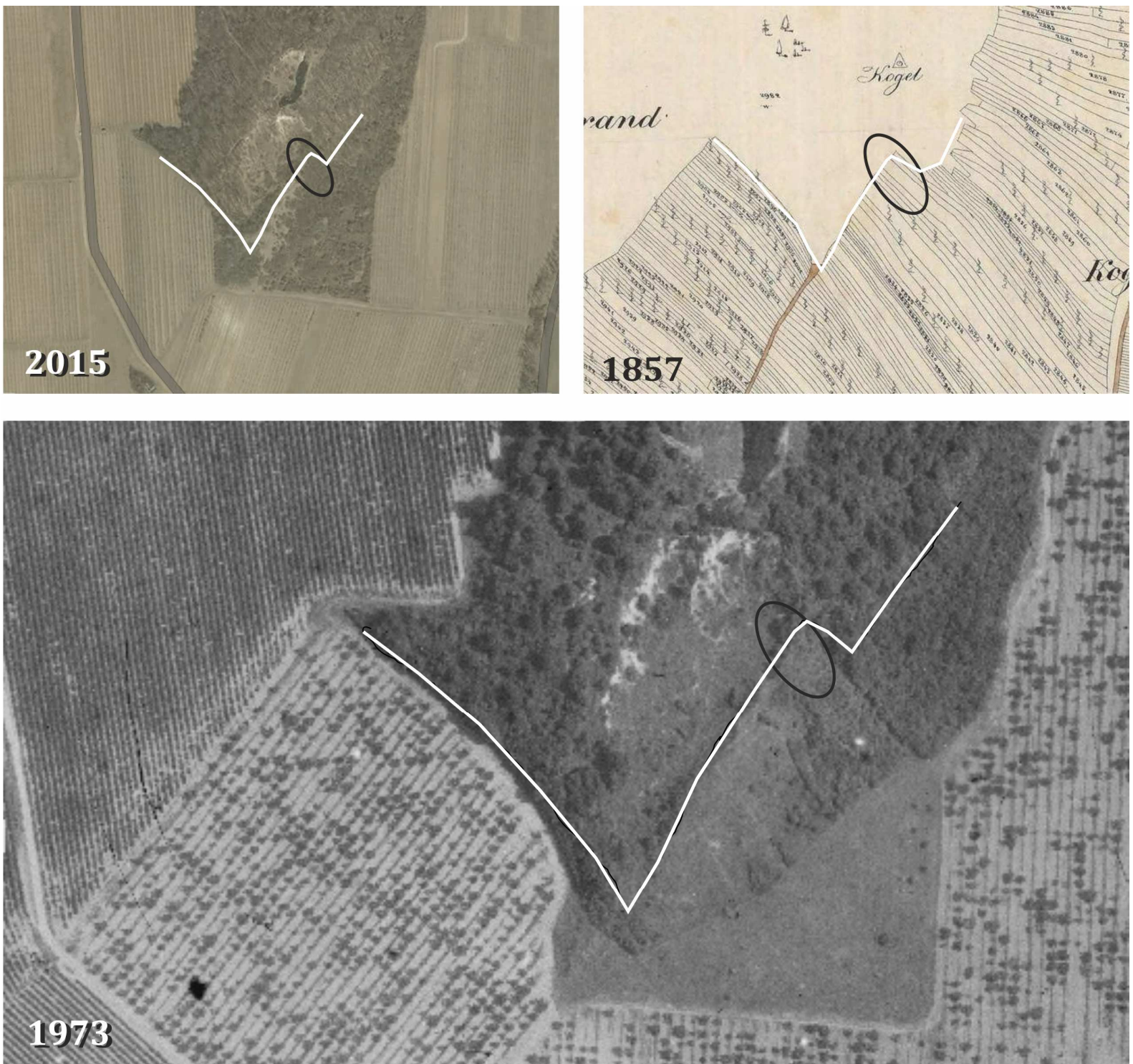

7. ábra. A Harkai-kúp azon része, ahol most a sallangvirágok vannak (ellipszissel jelölve), szőlőterület volt 1857-ben [2]. Vonal jelöli a szőlők egykori kiterjedésének határát. 1973-ban sem volt már szőlő [4] a Harkai-kúp azon foltjain, ahol ma erősen becserjésedett növényzetben és a még megmaradt csekély termőrétegú, meredek oldalakban nőnek a sallangvirágok. Az egykori szőlőparcellákra utalnak a sűrű növényzetben fellelhető obalák.

Fig. 7. That part of Harka Hill, where lizard orchids grow today (marked with ellipse), was vineyard in 1857 [2]. The line indicates the border of the vine parcels. There was no vine parcel in 1973 [4] where lizard orchids grow under the dense scrub today. 